\title{
Spanish in Sub-Saharan Africa: Whither Nigeria?
}

\author{
Purity Ada Uchechukwu \\ *http://dx.doi.org//I0.43/4/ujah.vI7i3.14
}

\section{Abstract}

The apparent lack of recognition of the need for Spanish as a foreign language is surprising in Nigeria where only one federal university offers Spanish (Uchechukwu, 2014). Even the Spanish government's Action Plans for Africa (200I-20I2), efforts at the diplomatic level to foster bilateral relationships through cultural exchange, and introduction of Spanish as a foreign and international language into the African continent did not have any resonancein Nigeria. Investigations however, confirm a tremendous increase in learning Spanish in many countries in sub-Saharan Africa with the francophone countries in the forefront (Serrano, 2014). This paper presents the situation of Spanish in Nigeria and poses the question of the country's standin this emerging trend in the West African sub-Saharan region.

Key Words: Spanish in Sub-Saharan Africa, Spanish in Francophone countries, Spanish in Nigeria

\section{Introduction}

The remnants of past colonial powers in the sub-Saharan region of Africa are still present today in the form of English and French as official or co-official languages in almost all the sub-Saharan countries in the continent. Nigeria's geographical location, with boundaries from the north to the south (the west being an exception) with French speaking countries, makes it important to learn the French language as enshrined in the country's National Policy on Education (NPE, 1988). It is, however, interesting to note that while geographical proximity has decided the need for French in Nigeria, a 
situation similar to the need for Spanish in Brazil (see Moreno, 2000). The francophone countries are in the forefront in the acquisition of Spanish in the West African region. With the growing trend in multilingualism as the norm in today's globalized world, the question is, where does Nigeria, and more especially, its institutions of higher learning, stand in this turn of events? This paper addresses this question as follows: Section two gives a brief overview of the position of Spanish as a global language alongside the efforts of successive Spanish government's Africa Plan (200I20I2).In section three, a brief summary of Spanishin Africa in the annual reports of the Spanish Cultural Institute, Instituto Cervantes(2005; 206-2007) provides insight into the presence and expansion of the language in the sub-Saharan region. Section four focuse son Spanish in Nigeria, the reasons for its general lack of presence not only in the institutions of higher learning, but in the country in general. Section five forms the summary and conclusion.

\section{Spanish: A Global Language}

Crystal (2003) declares English to be the world language based on specific criteria. When these criteria are considered with regard to the situation of Spanish in the world, it becomes apparent that Spanish fulfills them all and as such can also be regardedas a global language (see Uchechukwu, 2014a:182-185; Lago, 2013; Gómez, 2012; Bravo, 20II; López García, 2007;Marcos, 1994). With a growing trend, Spanish has become the second language of international communication and the second most studied language in the world (Caffarel, 2008: 20). And while the presence of Spanish in the Americas dates back to the period of discoveries and colonialism (see Fontanella de Weinberg, 1992; Dicker 1996; Noll 200I), its current prestigious position is strengthened by the steady rise in the number of Latinos or Hispanics in the 
United States where census figures there predict that in the year $2050,132.8$ million or $30 \%$ of the population will be Spanish speakers (Caffarel, 2008:20; Lago, 2008: 23); making the United States the continent with the second highest number of Spanish speakers in the world.

The most recent situational report on Spanish in the world,el español en el mundo(20I5), by the anuario of the Instituto Cervantes is a diachronic analysis that dates back to 30 years. Not only does the report give an overview of what obtained in 2015, it also identifies tendencies and points of strength as well as weaknesses for the right steps to be taken for the future of the language. For example, the need for more engagementin sub-Saharan Africa in view of the more than 1.2 million persons in the region studying Spanish; a just recently confirmed statistical data. The data from the report (20I5) in summary provides details on the level of expansion and scope of Spanish as a language of culture and communication:

- In 2015, almost 470 million persons have Spanish as their mother tongue.

- The group of potential users of the language (a combination of the group of native speakers, of speakers with limited competence, and the group of foreigners undergoing training in the language) has risen to almost 559 million.

- Spanish is after Mandarin Chinese, the second most spoken mother tongue in the world based on the number of speakers.

- For demographic reasons, the percentage of the world population that speak Spanish as its mother tongue continues to rise while the proportion of English and Chinese speakers is on the decline. 
- $6.7 \%$ of the world population is already Spanish speaking, a percentage that is much higher than Russian (2.2\%), French (I.I\%) and German (I.I\%).

- Forecasts estimate that in 2030 Spanish speakers will make up $7.5 \%$ of the total world population.

- More than 2I million students are studying Spanish in different parts of the world.

This latest edition of the anuario also presents data on the position of Spanish in the area of communication in the internet:

- Spanish is the third most used language in the internet; only behind English and Chinese.

$.7 .9 \%$ of users of the internet communicate in Spanish.

- Spanish is the second most used language in the two main social media networks: Facebook and Twitter.

- Spanish is the most used language in Twitter in the cities of London and New York.

In summary, Spanish is presented as a language on the rise, even more than the other European languages such as French and German. The weak point is sub-Saharan Africa that is not receiving as much attention due to previous lack of data with regard to the number of learners of the language. Whatexactly is the position of Spanish in sub-Saharan Africa? And what efforts, if any, have successive Spanish governments made with respect to promoting Spanish in this region? This is the focus in the next subsection.

\section{I Spain's Africa Plans (200 I-20 I 2)}

Apart from Western Sahara, a former Spanish colony that today is one of the territories under UN supervision and remains occupied by Morocco (see Andreu 2015; Munene);Equatorial Guinea is the only other African country in the West African sub region where Spanish is spoken for 
historical reasons of colonialism. Otherwise, the region appears to have little to do with the languageas Durántez(2004) explains:

“...el español es una lengua poco estudiada y promovida en un subcontinente donde predominan, como idioma oficiales, dos grandes lenguas internacionales, el inglés y el francés, seguidas delportugués..." (2004:I)

"...Spanish is a language that is studied and promoted by a few in a subcontinent where two great international languages, English and French, followed by Portuguese, predominate as official languages..."

Durántez (2004), therefore, proposed a 'subespacioiberoafricano', or an Iberian-African subspace to be made up of the five Lusophone countries of Cape Verde, Sao Tomé and Principe, Angola and Mozambique together with Equatorial Guinea based on their cultural and linguistic affinities with Spain (2004: 4). This body, in his opinion, was necessary to fill the gap in the region, create awareness and serve as a link between the Iberian Peninsula and Africa.

Gil and Otero (20I2)report on Spain's growing interest in sub-Saharan Africa for economic and cultural reasons. This renewed interest in Africa gave rise to intensification in diplomatic contacts, economic and developmental cooperation based on the awarenessof the opportunities, social, economic, as well as security challenges the growing continent could pose to Spain. Hence, the Spanish government strengthened external action in the region just as it had with the Asia-Pacific region in 2002. Subsequently, successive Spanish governments from the year 200 I drew out Africa Plans. 
The Africa Plan, El Plan África, is the framework utilized by the Spanish government to define Spanish foreign policy in Africa. Through this plan, the traditional, almost permanent absence of Spain in sub-Saharan Africa came to an end(Oda-Ángel, 2007).The first Africa Plan (200I-2003) was presented in 2000 based on a 'globalization of Spanish foreign policy 'by establishing a specific link between business interests, cooperation and migration. Among the six major objectives of this Plan was the promotion of Spanish language and culture in the region.

The next Africa Plan (2006-2008) arose as a directresponse to the migratory crisis of 2005-2006.One of the concrete strategic lines in the objective was the projection of the Spanish language in African countries 'where its implementation is very limited'in response'to a growing demand from African societies'. Spain officially declared itsprospects in the African Union in 2003; underlining the 'common purpose' of promoting Spanish in Africa with the opening of the Spanish Cultural Institute, Instituto Cervantes, in Equatorial Guinea. In addition, the establishment of Casa África in Las Palmas in 2007 was a decisive step in facilitating contacts with respective African societies.

The 2009-2012 Africa Plan, in its chapter on 'Linguistic Cooperation and promoting Spanish', supported the creation of a department of translators and interpreters of Spanish in the African Union, and facilitating access to the Spanish proficiency examinations, DELE, in Malabo and Bata.

A reflection of the achievements of the Africa Plans with focus on promoting Spanish is portrayed in the annual reports of the Instituto Cervantes. These comprehensive accounts (see Annual report of the Instituto Cervantes2005; 2006-2007) covered the situation of Spanish in Senegal, Ivory Coast, Burkina Faso, and Gabonas well as in the island of 
Madaga scaramongst others. All statistics presenter is ingtrend in the learning of Spanish in all these countries. Though the adoption of the French system of education in most of these countries facilitates the inclusion of Spanish as a foreign language in their school curriculum, exceptions are, however, noticeable in Anglophone countries such as Kenya and South Africa, where tourism plays a major role in the spread of Spanish (Cámara, 2006).

With these Africa Plans and reports on progress in learning Spanish in the sub-Saharan region, why does Nigeria not feature at all? Why such ignorance on the importance of the Spanish language? The only comment in the annual report from the Instituto Cervantes on Spanish in Anglophone countries in Africa (Gil and Otero, 20l2) had just one line about its presence in Nigeria which runs thus "en el gigante africano, Nigeria, hay un solo lector de la AECID en la Universidad de Abuya" i.e., in Nigeria, the giant of Africa, there is just a single lecturer from the AECID in the University of Abuja.

In 2014 a comprehensive documentation on Spanish in sub-Saharan Africa was realized through a joint collaborative effort with the Spanish language teachers, writers and officials in the whole sub-Saharan region and beyond. The result of this joint effort is documented in a 638 page volume titled, $\mathrm{La}$ enseñanzadelespañol en África Subsahariana (Serrano, 20l4). The research was undertaken during the time frame of 2012/2013-2014. This documentation portrays the efforts, in part, of the Africa Plans of the Spanish government towards promoting the language even in the most volatile regions in the continent.

Observable from the reports is that many teaching personnel are sourced from Spain through the AECID cooperation programme; and while it may be argued that the adoption of the French education system by most of these 
countries (being former French colonies), facilitates the spread of the Spanish language, the presence of Ghana, Gambia, Ghana, Kenya, Uganda, Tanzania, South Africa, Namibia, to name just a few Anglophone countries, is an indication of rising interest in Spanish, and highlights the importance of cooperation in this field of activity. Nigeria is included in the reports for the first time in the history of any report on Spanish in the West African sub-Saharan region. As this report was within the time frame of 2012/2013-14, what is the current situation of Spanish in Nigeria? Are there significant improvements? The next section provides answers to these questions.

\section{Spanish as a Foreign Language in Nigeria}

The French language enjoys a privileged position amongst other foreign languages in Nigeria for specific reasons as specified in the country's National Policy on Education (NPE 1988):

"For smooth interaction with our neighbours, it is desirable for every

Nigerian to speak French, accordingly, French shall be the second official language in Nigeria and it shall be compulsory in schools"

Though no other foreign language with the exception of Arabicis given such importance or relevance in the National Policy on Education (see NPE 2004), the citizenry is at liberty to learn foreign languages such as German, Russian, Chinese, and Spanish. So, why has the language of Cervantes not made much impact in Nigeria in spite of Nigerians' love for Hispanic culture, the Spanish La liga, and the football clubs Real Madrid, and FCBarcelona? Also, Feliz Navidadisa favourite Christmas songs for children and adults alike; but are they aware that they are singing in Spanish? The Latin American 
telenovelas also now form part of family entertainment. But most surprising of all is the almost total lack of knowledge of the contributions of Hispanics/Latinos of African descent, otherwise known as Afro descendants/Afro-Hispanics/Afro Latinos to the enrichment of the culture and spoken Spanish in Latin America. Evidence of which has been well documented by Lipski right from the 80 s (see Lipski, 1989; 1994; 1997; 1998; 2004; 2007; 2008). It was also not known in Nigeria until most recently that African religious practices such as Abakua, Santería, Candombe, Carabalí, or the practice of ancestor worship known as espiritismo by Afro-Hispanics exist in Spanish speaking America.

In the light of this situation Uchechukwu(20I4b) confirms that though learning Spanish as a foreign language is not at all widespread, the language had actually been studied in two Nigerian universities before the Nigerian Civil War. The Departmental Handbook of the Department of Modern Languages and Literature of the University of Nigeria, Nsukka UNN) which captures the history of the department, has it on record that Spanish was taught from 1960-1967 as an elective course in the Department until the outbreak of the Nigerian civil war. At that time, the present Department of Modern Languages and Literature was known as the Department of Foreign Languages and Literary Studies. Another federal university with a history of Spanish is the University of Port Harcourt (UNIPORT) where the language was included as one of the foreign languages in the Department of Foreign Languages and Literature from 19811985. Unfortunately, the University of Nigeria, Nsukka (UNN) and the University of Port Harcourt (UNIPORT) have not been able to resuscitate the Spanish programmes due to a lack of qualified teaching personnel.

Reflecting on the brief history of Spanish in UNN and UNIPORT alone, one is given an insight into how weak the 
impact of the Spanish language is,not only in the Nigerian society as a whole but, more specifically, in the Nigerian university system. Further investigations reveal that this is not due to a lack of interest in the language as such, but the result of a dearth of teachers and ignorance of the role and importance of Spanish in the world. Another reason could be because of the relevance of our French speaking neighbours and the need for Nigerians to learn French for easy interaction. One even hears the question, "what do we need Spanish for?" forgetting that the world is now a global village.

Looking at the issue from another angle, it would be interesting to find out the role of the Spanish government in promoting the learning of the language in Nigeria. The Africa Plans did not exempt Nigeria from its area of cooperation and development; even though all the Annual Reports from the Instituto Cervantes(2005; 2006-2007) did not have any reports from the country. The recent documentation project by Serrano (20/4) is an exception. What are the efforts of the Spanish government towards promoting its language in Nigeria? This is looked into in the subsequent subsection.

\section{I The Spanish Government and Promotion of Spanish in Nigeria}

The teaching of Spanish as a foreign language commenced in the University of Abuja (UNIABUJA) in 2004 through a cooperation with the Spanish Agency for Cooperation and International Development, AECID. The AECID provided UNIABUJA with a lecturer from Spain, but on a two-year contract basis. This implied that at the expiration of the contract, the lecturer had to return to Spain; and a new lecturer was contracted from Spain. In all, UNIABUJA had a total of five Spanish lecturers from 2004 to 2012.

Another area is the cooperation between the AECID and the National Union of Universities (NUC). For the first 
time in the history of Nigeria, the Spanish embassy in collaboration with the NUC in 2010, organized the first AECID-NUC Programme, Spanish Training Programme for Nigerian University Lecturers at the NUC headquarters in Abuja. The aim of this programme was to sensitize, create awareness and showcase the relevance of the Spanish language in the world, with its possible introduction into the Nigerian university system. Nigerian universities which sent participants included the University of Nigeria, Nsukka (UNN) Nnamdi Azikiwe University, Awka (UNIZIK), University of Ilorin (UNILORIN) and Ebonyi State University, Abakaliki (EBSU). The Training took place from $18^{\text {th }}$ June to $13^{\text {th }}$ July, 2010.A second Spanish Training Programme for Nigerian University Lecturers, another cooperative venture between the AECID and the NUC took place from $3 I^{\text {st }}$ May to $25^{\text {th }}$ June, 2012. This time, with even less participation from Nigerian universities -Nnamdi Azikiwe University, Awka (UNIZIK), University of Port Harcourt (UNIPORT), Michael Okpara University, and a representative from the French Cultural Institute, Alliance Française.

The summary of the workshop attendance can best be described discouraging for some obvious reasons. Reflecting on the Programme itself, one could deduce the reason for the almost non participation of many Nigerian universities: The idea was a good one, being the first of such a sensitizing effort to promote the Spanish language and culture in Nigeria in general. However, one could not envisage a concrete plan in the concept. This became evident when the participating lecturers on their return to their respective institutions were confronted with questions that ranged from reasonable to outright ridiculous. To the former belong the concrete arrangements on the part of the organizers towards introducing Spanish in the Universities that sent participants, if the participants could now sit for the 
basic level (AI) Spanish Diploma Certificate Examinations (DELE), in addition was the question of the availability of didactic materials. To the latter enquiries was if the participants could begin outright to teach in their respective institutions and if the whole venture was not just a jamboree.

In all, the workshops neither left much resonance nor yielded any fruits for two reasons. In the first instance, there were no indications of future concrete plans on the part of the collaborators i.e., the AECID and NUC, for the establishment of Spanish units in the participating universities. Secondly, the participants were not equipped to write even the basic DELE examination (AI). Exceptions were the participants from UNIZIK, who already had a doctorate degree in Spanish linguistics and the participant from the French Cultural Institute, Alliance Française who had a BI DELE certificate in Spanish proficiency. Consequently, the rationale behind both Programmes was questioned in the participating universities.

Spain's economic crisis put a halt to the AECID-NUC cooperation in 2012. Consequently, after the first semester of 2012, the last Spanish lecturer at UNIABUJA had to return to Spain. The students who had chosen Spanish as their elective had Italian as the only other available elective course. Meanwhile, the University had recorded a total of 165 students studying Spanish as a foreign language in 201 I.Because of the contractual nature of the AECID-NUC agreement, the status of the Spanish language did not rise above that of an elective course i.e., with only one teaching personnel, who on expiration of the contract had to always return to Spain. It naturally follows that a degree programme could not be developed under such conditions. Hence, Spanish remained an elective course studied only by students of the Department of English and Linguistics in UNIABUJA 
for almost eight years of the duration of the Cooperation Programme.

Currently, there is only one available possibility to study Spanish as an elective course in a federal university in Nigeria at Nnamdi Azikiwe University, Awka (UNIZIK). The challenges and efforts of its implementation are discussed in the next chapter.

\section{Spanish at Nnamdi Azikiwe University: Problems and Prospects}

Situated within the Faculty of Arts of NnamdiAzikiwe University, Awka is the Department of Modern E uropean Languages (MEL). The Department runs three programmes: the Regular four-year degree programme, the Continuous Education Programme (CEP- six years), and the Diploma Programme of two years. All students of the aforementioned Programmes major in French. German served as the only elective course from 1999 until the introduction of Spanish as a second foreign language elective course in 2010.

The conditions involved in the teaching of Spanish as a foreign language in UNIZIK are quite different from what obtained in UNIABUJA. In the first place, the Spanish lecturer is fully employed by the University and is neither on contract nor in cooperation with the AECID. Also, all students of MEL in the Regular, CEP, and Diploma Programmes have the choice of either German or Spanish as an elective. This situation is favourable in the sense that students can choose between two foreign languages. However, for its implementation in 2010, the first question was how to implement this effectively? The students were, after all, expected to choose either language as an elective course. The decision taken by the Board of MEL was to allow all students participate voluntarily in both classes for at least two weeks and thereafter decide on one of the electives. 
There have been some positive developments since the introduction of Spanish in 2010. There is now a growing awareness in the country about the language; though some misconceptions still remain with regard to it being the only language in Spain. More students from other faculties in UNIZIK are showing interest in learning Spanish. Some students of the Chinese Confucius Institute, for example, now choose Spanish as their elective instead of French or German. The demands from more departments, and even faculties, cannot be met because the question of insufficient teaching personnel remains the same six years after the introduction of the language as an elective course.

The level of the course as well as the conditions under which it is studied have not undergone any changed since its inception at the time of the documented report (see Uchechukwu,20I4b: 48I-492) i.e., the students all still major in French, travel to a francophone African country, or any other French speaking country for the Year Abroad Programmein their third year of study, and spend two semesters there i.e., one whole year to improve most importantly, on their communication skills. The same obtains for those in the CEP programme, who in their fourth year, go on the Year Abroad Programme. The Diploma Programme is being phased out this year; but the last batch of students from the 2015/2016academic semester learned Spanish for two years; and will eventually be absorbed into the Departmental Regular Programme as second year students based on merit. They will eventually continue with Spanish as their elective until they go on the immersion Programme to a francophone African country in their third year.

The consequence of this state of affairs impacts on the level of acquisition of the language by the students. It is a condition that affects the lecturer, in the first instance, and the students in the second. First of all, after the Year Abroad 
Programme, the Spanish lessons are begun almost afresh for all students who have the language as their elective. This is a necessary step because of loss of proficiency in the language during the Year Abroad Programmein a French speaking country. The onerous task of revising the elementary levels I and II as a form of gradual reorientation lies with just one Spanish lecturer. Consequently, the Students' proficiency in Spanish at the conclusion of their four year French degree programme remains at the intermediate $(\mathrm{BI})$ level.

Another important factor affecting the teaching of Spanish at UNIZIK is the almost non availability of didactic teaching materials in the form of magazines, journals, and literature in the Spanish language. Investigations by the author at UNN University library presented a picture of old teaching materials and workbooks. Nevertheless, the library is home to some classic Latin American literary works by renowned Latin American authors such as Gabriel García Márquez, Alejo Carpentier, etc. These materials still bear the decade old stamps of some American donor organizations. A similar investigation in UNIZIK library showed that through the Nigerian Book Foundation, some Spanish didactic materials from American donor organizations are actually available; though old and few in number.

\section{I Prospects}

At the introduction of Spanish as an elective course in UNIZIK in 20I0, 12 students in all decided to 'try' learning a language they had never heard before. In 2011 , the number rose to 53 and in the current 2015/16 academic session, the department has a total of 174 students (Regular, CEP and Diploma students) studying Spanish as an elective course. This is progress and a clear indication of genuine interest in 
spite of the challenges of dearth of didactic materials and lecturers.

The relevance of technology as a complementary tool in the teaching of foreign languages has, to a great length, impacted positively on foreign language acquisition in the western world (see Bradley, 2013; Thouësny and Bradley, $20 \mathrm{II}$ ). To this end, the scarcity of books and other didactic materials is being complemented through the use of free downloadable online materials for learning Spanish. These materials come in the form of puzzles, quizzes, competence tests and even e-books. The students who opt for Spanish as an elective course in MEL now have access to these interactive online tests and lessons from free online Spanish websites as part of their classes. The challenges that come along with this effort, such as power outages, notwithstanding, it is a step towards accessibility to online learning.

The Spanish oral classes are more practical oriented through on line interaction with native speakers of Spanish. By this, the difference in Latin American and Peninsular Spanish is easier to identify, and students do not get confused about this aspect in the comprehension classes. Also with exciting videos and short films, the classes could even be more exciting and educative if not for frequent power outages.

To the more recent and positive developments include the assistance from the Spanish Foundation, mujeresporáfrica(mujeresporafrica.es). This Foundation extended cooperation to Nnamdi Azikiwe University, Awka in 2014 through an invitation of the Spanish lecturer to the Congress of African Female Hispanists, el congreso de his panistasafricanas in Ivory Coast. The congress was a rich intellectual exchange that afforded the participant insight into the teaching of Spanish, the position of Spanish in the world 
as well as contact with the Hispanic world. Perhaps the greatest boost to the spread of Spanish in UNIZIK is the offer of scholarship from the University of La Rioja in Spain to a student of MEL. This scholarship has had beneficiaries over the years, mostly students from the francophone countries and Ghana. This is the first time a Nigerian student in a Nigerian university is benefiting from this offer and gives hope for continuity in the learning of Spanish as a foreign language in UNIZIK.

\section{Summary and Conclusion}

Language and effective communication according to Gutiérrez and Landeros (2010)are the main tools of socialization in a globalized world and the individual who can speak a second language has acquired the necessary tools needed in today's globalized world to access knowledge and learn from diverse cultures (2010: 105).But, how do you learn to be enthusiastic about a language you never use in your environment?

To motivate the very first students who opted for Spanish in 2010, the first class had to be a cultural adventure, which subsequently, set the standard for future classes. This cultural adventure cut across the history of Spain, Latin America, Hispanic art and culture, and the relevance of the Spanish language in the international scene. However, and in line with the suggestion of Villegas that "teachers ... should make every effort to include and present the African contributions as well as the European and the Amerindian themes with equal respect and enthusiasm...only then will the picture of Latin American culture be complete" (2006: 57I), the contributions of Africans to the development of Hispanic culture take center stage in the cultural exercise. This aspect of the African presence in particular, motivated and still motivates students of MEL to select Spanish as their 
preferred elective course. Davis and Markham (199I) arrived at a similar conclusion when through their investigations they found out that $40 \%$ of African-American students believe that a foreign language would be more relevant to them if African themes were treated.

The next necessary step would be an upgrading of the course from the level of an elective to a full-fledged degree programme. To this end, establishing collaborative agreements with Spanish universities will be a step in the right direction. Additionally is the need to establish partnership between Spanish publishers and their counterparts in Nigeria so that didactic materials, magazines, books written in Spanish can become accessible nd affordable.

Finally, to effectively communicate with, and foster closer ties with those outside her immediate vicinity, to identify with the struggles for equality of Afro descendants in the Spanish speaking world, to recognize the efforts of the Saharawi, "a people with distinct cultural attributes including a hybrid language shaped by long interaction between peoples from within and outside of Africa" (Munene, 20I0: 83)towards the decolonization of Western Sahara, Nigeria, the most populous African country in the world, needs the language of Cervantes.

Purity Ada Uchechukwu Department of Modern European Languages Nnamdi Azikiwe University, Awka 


\section{Referencies}

Andreu Mediero, Beatriz (2015): "Sahara occidental: recursos naturales y economía". Paper presented at the Conference of Academic Staff Union of Universities (ASUU) International Conference:"Towards the liberation of Africa's last colony". Abuja, Nigeria $2^{\text {nd }}$ 4th June $20 I 5$.

Bradley, L. (2013). Language learning and technology Student activities in web-based environments. Go then burg Studies in Educational Sciences 330.

Bravo, G. (20l I): 'El español internacional: valoración actual y usos específicos. Lengua y sociedad en el mundo hispánico', in Language and Society in the Hispanic World. Vol. 27, pp. 49-7I. Iberoamericana.

Caffarel Serra, C. (2008): 'Estados Unidos: el presente y futuro del español'.

Anuario del Instituto Cervantes. 2008, pp. 19-2I. Consultado el 14 de abril de 2014 desde: http://crc.cervantes.es/lengua/anuario/anuario_08/pdf Ipreliminares_0l.pdf

Cámara Escriba, R. (2006): El español en Kenia", en Enciclopedia del español en el mundo. Anuario del Instituto Cervantes 2006-2007, Instituto Cervantes, Madrid; Plaza \&Janés, Círculo de lectores, Barcelona, pp.77-80.

Crystal, D. (2003).English as a Global Language.(Second edition).Cambridge: Cambridge University Press. 
Davis, J. \& Markham, P. "Student Attitudes toward Language Study at Historically and Predominantly Black Institutions". Foreign Language Annals 24 (1991): 227-37.

Dicker, S. J. (1996).Languages in America. A Pluralist View. Bilingual Education and Bilingualism. United States: 10. Multilingual Matters Ltd.

Durántez Prados, F. (2004): El idioma español en África subsahariana: aproximación y propuestas. Real Instituto Eleano. Área: Lengua y cultura- ARI N ${ }^{\circ}$ 146/2004. Fecha 28/09/2004,pp I-5.

El español en el mundo. Anuario del Instituto Cervantes(2005). Instituto Cervantes, Madrid; Plaza \&Janés, Círculo de Lectores, Barcelona.

http://crc.cervantes.es/lengua/anuario/anuario_05/morgades/p $01 . h t m[c o n s u l t a d o$ el 10 de septiembre de 20I2].

Enciclopedia del español en el mundo. Anuario del Instituto Cervantes 2006-2007, Instituto Cervantes, Madrid; Plaza

\&Janés.http://cvc.cervantes.es/lengua/anuario/anuario _06-07/pdf/paises_05.pdf[consultado el 18 de septiembre de 20I2].

Federal Republic of Nigeria (1998): National Policy on Education, $3^{\text {rd }}$ ed., Nigerian Educational Research and Development Council Press, Lagos.

Federal Republic of Nigeria (2004): National Policy on Education, $4^{\text {th }}$ ed., Nigerian Educational Research and Development Council Press, Lagos. 
Fundación Mujeres por África. www.mujeresporafrica.es.

GilPedrodomingo,L. \& Otero, R. (2012): Perspectivas de la lengua española en África subsahariana.http://cvc.cervantes.es/lengua/anuario/a nuario_09/gil_otero/p0l.htm

Gómez Font, A. (20I2): 'Español neutro o internacional'. Consulted on $27^{\text {th }}$ July, 2014: http://www.fundeu.es/escribireninternet/espanolneutro-o-internacional.

Gutiérrez Ramírez, M.; Landeros Falcón, I. (2010). Importancia dela lenguaen el contexto de la aldea global. Horizontes Educacionales, vol. 15, núm. I, 2010, pp. 95-107. Universidad del BíoBío. Chillán, Chile.

Lago, E. (2008): 'Estados Unidos Hispanos'. CVC. 2008. Anuario del Instituto Cervantes, pp. 23-26.

Lago, E. (2013): 'La literatura hispana se convierte en potencia cultural enEE.UU'. Consultado el 14 de marzo de 2014 desde: http://cultura.elpais.com/cultura/2014/0I/23/actual

Lipski, J. (1989): The Speech of the Negro Congos of Panama: A Vestigial Afro-Hispanic Creole.Ámsterdam: Benjamins.

Lipski, J. (1994): "El lenguaje afroperuano: eslabón entre África y América”, Anuario de Lingüística Hispánica, 10, pp. 179-216. 
Lipski, J.(1998): "Latin American Spanish: creolization and the African connection", Publications of the Afro-Latin American Research Association (PALARA), 2, PP. 54-78.

Lipski, J. (1999): "Creole-to-creole contacts in the Spanish Caribbean: the genesis of Afro-Hispanic language", Publications of the Afro-Latin American Research Association (PALARA), 3, Pp. 5-46.

Lipski, J. (2004): “Nuevas perspectivas sobre el español afrodominicano. Pensamiento lingüístico sobre el Caribe insular hispánica". En Valdés Bernal, S. (dir.): Pensamiento lingüístico sobre el Caribe insular hispánico, Academia de Ciencias de la República Dominicana, Santo Domingo, pp. 505-552.

Lipski, J.(2007): "A blast from the past: ritualized AfroHispanic linguistic memories (Panama and Cuba)", Journal of Caribbean Studies, 21 (3), pp. 163188.

Lipski, J. (2008): Afro-Bolivian Spanish. Vervuert/lberoamericana, Frankfurt am Main.

López García, Á. (2007): El boom de la lengua española. Análisis ideológico de un proceso expansivo. Madrid: Biblioteca Nueva.

Marcos Marín, F. (1994): 'El español, lengua internacional. Ensayo: La lengua española, hoy (XIX), en Boletín Informativo. Fundación Juan March, $\mathrm{n}^{\circ} 239$.

Munene, M.(2010): "History of Western Sahara and Spanish Colonisation of the territory," in Botha, N. and 
Olivier, M. and van Tonder, D. (eds.). Multilateralism and International Law with Western Sahara as a Case Study (Pretoria: University of South Africa Press, 20I0), pp. 70-98.

Noll, V. (200I). Das amerikanische Spanisch. Ein regionaler und historischer Überblick. Tübingen: Max Niemeyer VerlagGmbH.

Oda-Ángel, F. (2007): España en el África subsahariana: multilateralismo eficaz: dspace.uah.es/dspace/handle/I00I7/7882.

Serrano Avilés, J. (2014).La enseñanza del español en África Subsahariana. Madrid. Editorial: Instituto Cervantes, Casa África y Editorial Los Libros de la Catarata.

Thouësny, S. \& Bradley, L. (20II). Second Language Teaching and Learning with Technology: Views of Emergent Researchers. (C) 20II by research-publishing.net

Uchechukwu, P. A. (20|4a). Globalización y la lengua española en los Estados Unidos como seña de identidad americana. Revista Scientífica de Comunicación Aplicada.http://journals.sfu.ca/indexcomunicacion/inde x.php/indexcomunicacion/article/view/I47// 35

Uchechukwu, P. A. (20|4b): "La situación del español en Nigeria" en Serrano Avilés, J. (ed.).La enseñanza del español en África Subsahariana. Madrid. Editorial: 
Instituto Cervantes, Casa África y Editorial Los Libros de la Catarata, pp. 48I-492.

Villegas Rogers, C. (2006): Improving the Visibility of AfroLatin Culture in the Spanish Classroom. Hispania 89.3 (2006): 562-573. Downloaded from 197.210.227.79 on Tue, I0 Nov 2015 17:31:3। UTC 